\title{
Indicators of Yield of Tithonia diversifolia in the Zone of Granma Province, Cuba
}

ISSN: 2637-7659

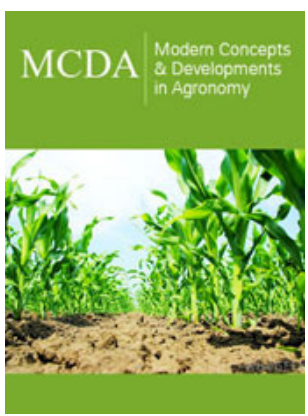

*Corresponding author: Verdecia DM, Animal Production Study Center, University of Granma, Cuba

Submission: 偰 May 06, 2020

Published: 啙July 02, 2020

Volume 6 - Issue 4

How to cite this article: Paumier M, Verdecia DM, Ramírez JL, Herrera RS. Indicators of Yield of Tithonia diversifolia in the Zone of Granma Province, Cuba. Mod Concep Dev Agrono. 6(4). MCDA. 000645. 2020. DOI: 10.31031/MCDA.2020.06.000645

Copyright@ Verdecia DM, This article is distributed under the terms of the Creative Commons Attribution 4.0 International License, which permits unrestricted use and redistribution provided that the original author and source are credited.

\author{
Paumier $\mathrm{M}^{1}$, Méndez Martínez $\mathrm{Y}^{3}$, Torres $\mathrm{E}^{3}$, Sánchez $\mathrm{AR}^{3}$, Ramírez JL ${ }^{1}$, Herrera \\ $\mathrm{RS}^{2}$, Santana $\mathrm{A}^{1}$ and Verdecia $\mathrm{DM}^{1 *}$ \\ ${ }^{1}$ Animal Production Study Center, University of Granma, Cuba \\ ${ }^{2}$ Institute of Animal Science, Cuba \\ ${ }^{3}$ Technical State University of Quevedo, Extension La María, Mocacha-Los Ríos, Ecuador
}

\begin{abstract}
The Tithonia diversifolia is a plant that has a large root volume, a special ability to recover nutrients from the soil, even when they are found in small proportions, its wide range of adaptation allows it to reach high productions of livestock feed. In order to establish the relationship between age and performance indicators of this species in the edaphoclimatic conditions of Cauto Valley, the study was developed following a randomized block design, with five treatments $(60,90,120,150$ and 180 days). The production of total, edible biomass and dray matter yield (DMY) were evaluated; as well as the establishment of the relationship between these and the days of the forage, regression equations (linear, quadratic, cubic, logarithmic and gompertz) were analyzed and the descending method was used for their selection. With increases as plant maturity progresses, the best results were obtained at 180 days $(46.18 \mathrm{t} \mathrm{GM} / \mathrm{ha} ; 10.96 \mathrm{t}$ $\mathrm{DM} / \mathrm{ha}$ ), during the rain for total foliage and DMY, while the edible biomass in dry season with $16.20 \mathrm{tGM}$ / ha; with first, second and third order function settings and R2 higher than 0.90 in both climatic season. The established models explain the close relationship between dependent and independent variables, with their increase in both seasonal periods.
\end{abstract}

Keywords: Shrub; Biomass; Equations; Age; Yield

\section{Introduction}

The Tithonia diversifolia known as a useful plant as an improved in soil fertility, mainly when it is handled as green manure, mixed with the soil or as an accompanying crop. This is a species that prevents erosion [1]. It is used in live fences, as flora for beekeeping, in medicine and in silvopastoral cattle. It is also used as cutting fodder for pigs, sheep, rabbits, cows and buffalo. It has the potential to feed ruminant and monogastric animals and is a forage of high nutritional value [2]. Taking into account the potential (quantitative and qualitative) forage of this species, which is listed as promising for sustainable systems of agricultural production, it is necessary to expand the scientific evaluation of the productivity of its forage in Cuba [3]. Therefore, the objective of this work is to establish the relationship between age and performance indicators of the shrub Tithonia diversifolia in the edaphoclimatic conditions of Valle del Cauto.

\section{Material and Methods}

\section{Research area, climate and soil}

The study was carried out in the Teaching-Productive Department of the University of Granma, which is located in the southeast of Cuba, $17.5 \mathrm{~km}$ from the city of Bayamo. The experiment was carried out for two years (2014-2015), and two seasonal periods were considered, the rainy (May-October) and dry (November-April). The soil present in the area was Calcic hastustept [4], with a pH of 6.2. The content of $\mathrm{P}_{2} \mathrm{O}_{5}, \mathrm{~K}_{2} \mathrm{O}$ and total $\mathrm{N}$ was $2.4 ; 33.42$ and 3 (mg/100g of soil) respectively, with $3.6 \%$ organic matter. Regarding the behavior of climatic variables, during the rainy season, rainfall was $731.4 \mathrm{~mm}$; the average, minimum 
and maximum temperature and relative humidity registered values of $26.73 ; 22.31$ and $33.92{ }^{\circ} \mathrm{C}$ and $80.78 ; 51.02$ and $96.22 \%$, respectively. In the dry season, the pluviometry reached values of $270 \mathrm{~mm}$; the temperature was $24.05 ; 18.29$ and $31.58{ }^{\circ} \mathrm{C}$ and the relative humidity of $76.21 ; 44.16$ and $97.03 \%$, in both cases for the mean, minimum and maximum averages.

\section{Experimental design and treatments}

A random block design with four replicates was used and the treatments were the regrowth ages of $60,90,120,150$ and 180 days.

\section{Procedures}

The established species had $98 \%$ of the population and at the beginning of each seasonal period a homogeneity cut was made at $15 \mathrm{~cm}$ above the ground level. The samplings were carried out in 10 plants in a row eliminating the edge effect in an area of $0.5 \mathrm{ha}$ 1 , according to the treatments. The sample was homogenized and weighed to determine the total biomass and dry matter yield, later they were separated manually into leaves, petioles and stems with a diameter less than $2 \mathrm{~cm}$ to know the edible biomass. Then two kilograms were taken for each of the treatments for the determination of the MS. During the experimental stage, no irrigation or fertilization was applied.

\section{Statistical calculations and analysis}

The relationship between performance and age was established through regression analysis using the following expressions: linear, quadratic, cubic, logarithmic and gompertz where the one with the best fit was used for the results, for which they were taken in counts the criteria of [5-7]. The high value of the coefficient of determination $\left(\mathrm{R}^{2}\right)$, high significance of the expression and its parameters, low standard errors; as well as the analysis of variance of the regression. The SPSS version 22 statistical system was used.

\section{Result and Discussion}

The total biomass increased $(\mathrm{P}<0.001)$ up to 180 days in Tithonia diversifolia (Figure 1) by 46.18 and 44.20 t GM (green material)/ ha, for the rainy and dry season, respectively. Quadratic and cubic equations were adjusted for the two cases. The edible biomass in Tithonia diversifolia (Figure 2) during the rain increased by $2.94 \mathrm{t}$ GM/ha until 120 days and then decreased until 180 days, while during the rainy season it increased $10.96 \mathrm{t} \mathrm{GM} /$ ha at 180 days, with adjustment to quadratic equations in both cases. For the dry matter yield (Figures 3 ) the greatest results were at 180 days with increases of 16.09 and 15.93t DM/ha, and linear curve adjustments for the seasonal periods of rain and dry, respectively. Total, edible biomass and dry matter production increased with the age of the regrowth (Figures 1-3), although the useable by the animal in the rainy season decreased after 120 days. This behavior can be attributed to the prevailing conditions for the growth of the plant, with which it reaches a greater size and degree of development. This affects, above all, the most woody parts, which explains why an increase in the useful biomass is not always observed despite prolonging the study time [8].

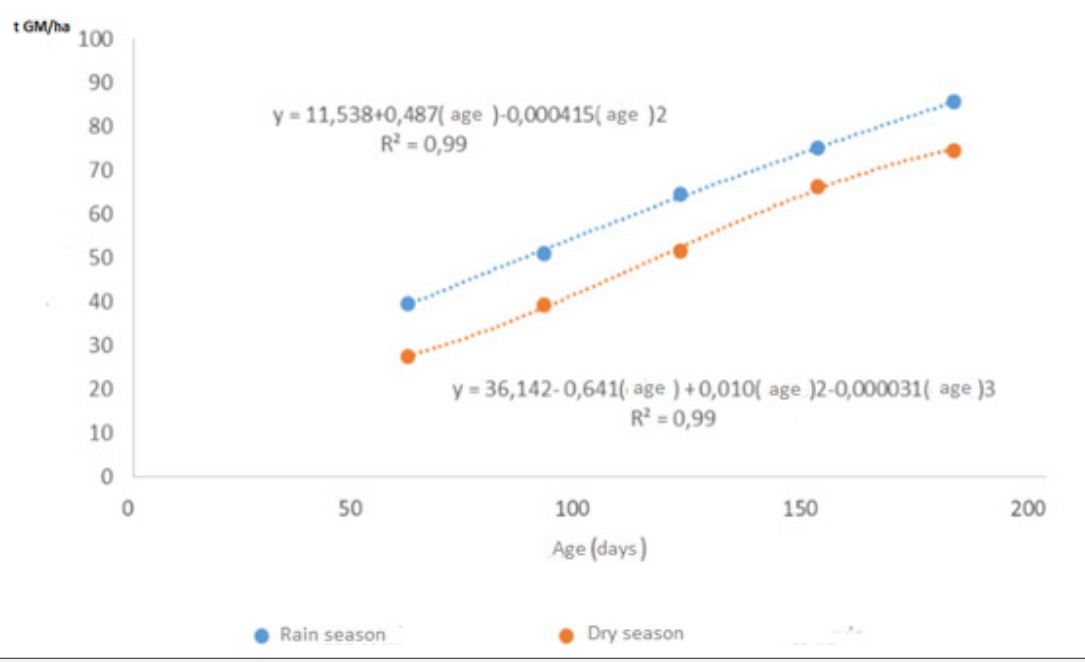

Figure 1: Total biomass of Tithonia diversifolia in both periods of the year.

The DM increased with the regrowth age, due, among other aspects, to the increase in its structural components. The studies of Rios [9] showed similar values to those found in this investigation at the age of 180 days, although the climatic conditions were different. The results of this investigation coincide with those reported by Mahecha and Rosales [10]; Ruiz et al. [3], who reported that as the regrowth age advances, there is greater development of the supporting tissues and an increase in the proportion of stems in the useful biomass. This increases the plant cell wall and decreases the cell content, differences that can be accentuated in the rainy season. On the other hand, Verdecia et al. [8], when studying the behavior of T. diversifolia in Valle del Cauto conditions, they found a decrease of $0.5 \mathrm{t} \mathrm{GM} /$ ha of useful biomass in the one with the rain season, from 120 to 180 days, these results are lower than those reported 
in this study with a decrease of $1.77 \mathrm{t} \mathrm{GM} / \mathrm{ha}$, due to the variability of climatic conditions in this region of the Cuban East, among other aspects.

When carrying out studies for Ruiz et al. [11], of the biomass production given by Tithonia diversifolia when using different planting densities and cutting heights, when using 2.66 plants $/ \mathrm{m}^{2}$, a marked effect of the amount of shrubs and height on the variables evaluated. Yields under these conditions were 82, 57 and 46t GM/ ha, respectively. In studies of Sanchez et al. [12] reported the highest values for edible biomass in Leucaena from 3.81 to $3.88 \mathrm{t} \mathrm{GM/}$ ha at 90 days of cut. An aspect of great importance for the management of the species because the production of edible biomass (non-lignified stem-leaves) of the shrub legumes tends to describe a curve where, in a first phase, they experience a sustained increase until reaching maximum yield. achieving a satisfactory leaf-stem relationship; in the next, this behavior declines significantly, with the presence of the woody part prevailing.

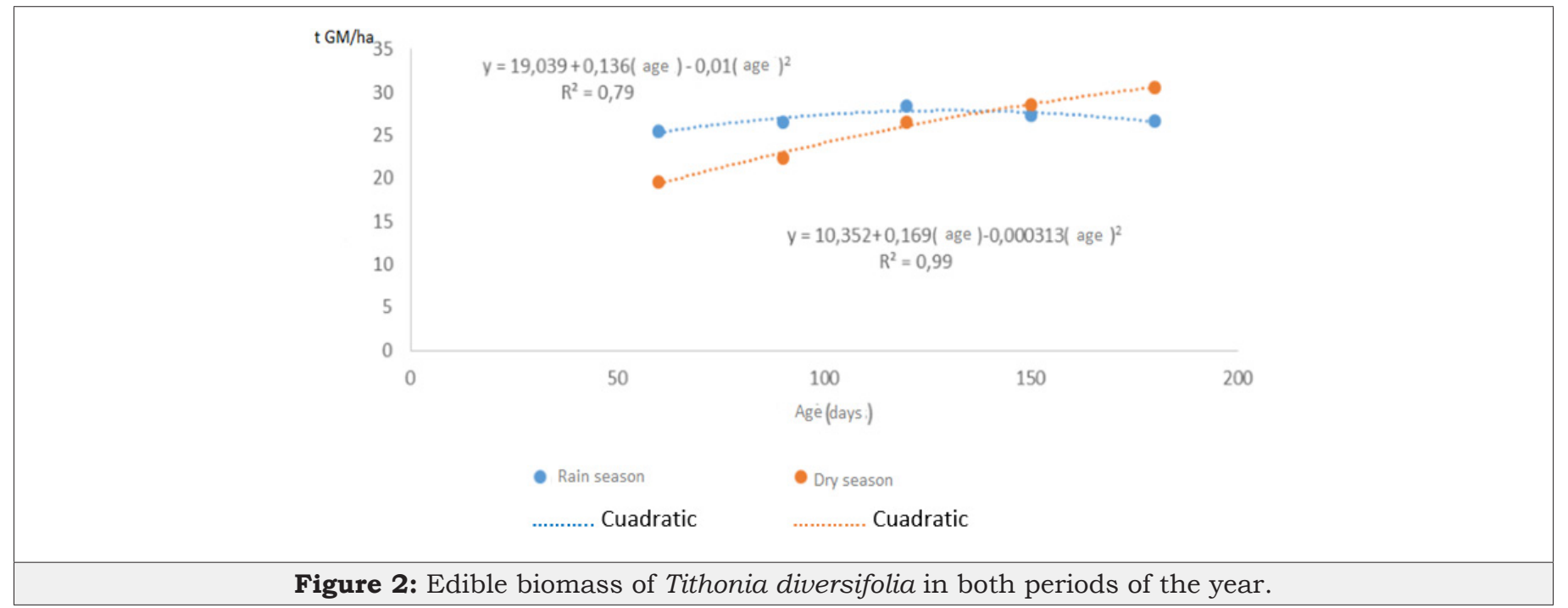

Figure 2: Edible biomass of Tithonia diversifolia in both periods of the year.

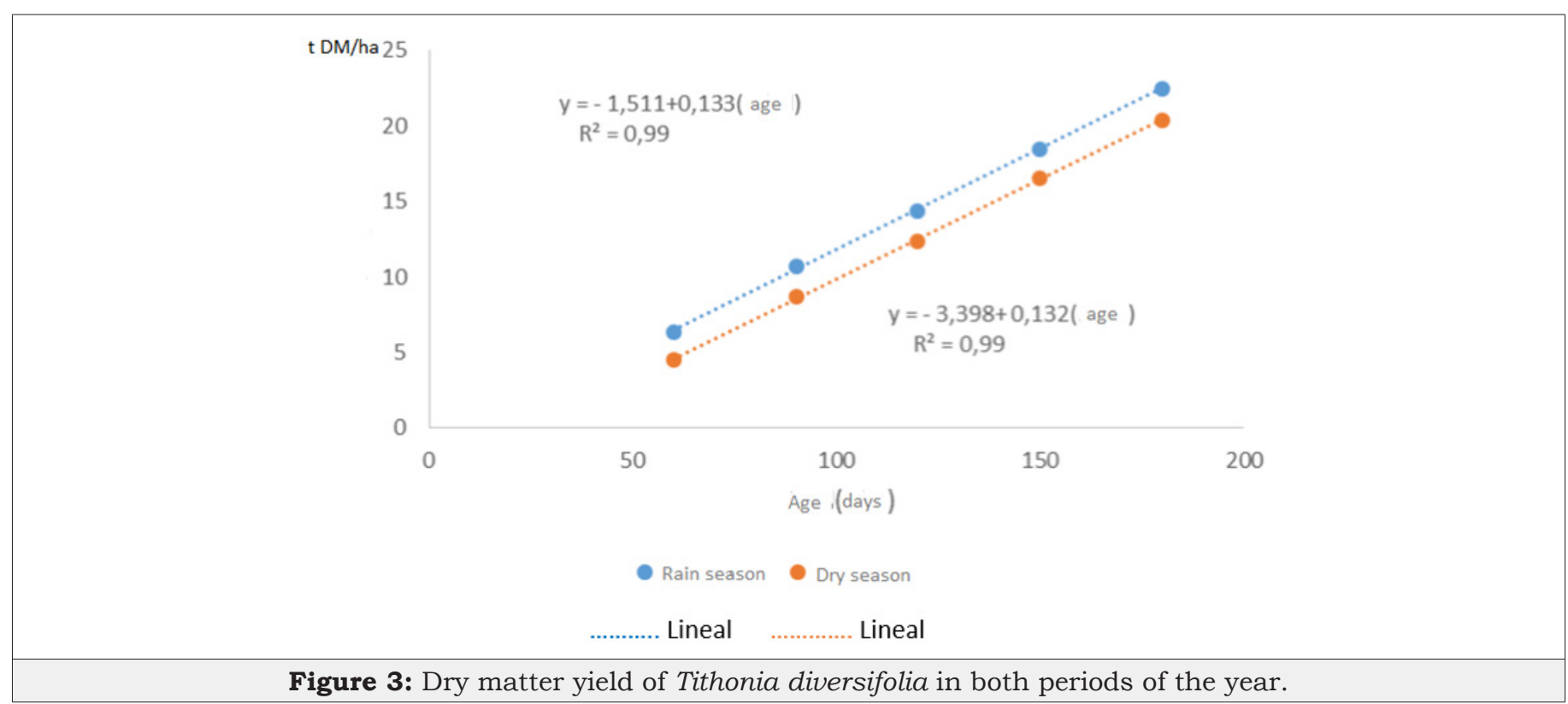

When evaluating Mendoza et al. [13] Brosimum alicastrum in different areas of Yucatan (Mexico), they found an increase in yield with the age of the plant, with its greatest results at 12 months with $2.13 ; 2.26$ and $11.85 \mathrm{Kg} \mathrm{DM} /$ tree, this behavior is attributed to the fact that by increasing the cutting phase it allows the plant to increase the leaf area, and with it its photosynthetic capacity and higher production. On the other hand, Simon et al. [14], it states that the trees during the first weeks after cutting, enter a slow recovery stage, mainly caused by the limited amount of carbohydrates, until the plant manages to have new leafy shoots capable of carrying out the photosynthesis that help this to a stage of rapid growth and accumulation of dry matter. When studying the effect of regrowth age Sosa et al. [15], they found the highest yields at 12 weeks with 2 and 0.90 tMS / ha for the rainy and dry periods, respectively. Behavior attributed to the prevailing edaphoclimatic conditions, hence the differences found between this study and the current one where 
productions are higher with 10 and 7 tMS/ha in each of the climatic stations.

\section{Conclusion}

The established regression equations explain the close relationship between the regrowth age and the performance indicators, with the increase of these in both seasonal periods.

\section{References}

1. Crespo G, Ruiz TE, y Alvarez J (2011) Efecto del abono verde de Tithonia (T. diversifolia) en el establecimiento y producción de forraje de P. purpureum vc. CT-169 y algunas propiedades del suelo. Revista Cubana de Ciencias Agrícolas. 45(1): 79-82.

2. Mahecha E (2005) Valor nutricional del follaje de botón de oro (Tithonia diversifolia (Helmsl.) Gray, en la producción animal en el trópico. Livestock Research for Rural Development p. 17.

3. Ruiz TE, Febles GJ, Galindo JL, Savon LL, Chongo BB, et al. (2014) Tithonia diversifolia, sus posibilidades en sistemas ganaderos. Revista Cubana de Ciencias Agrícolas. 48(1): 79-82.

4. Hernández A, Ascanio MO, Morales M, y Cabrera A (2005) Correlación de la nueva versión de clasificación genética de los suelos de cuba con las clasificaciones internacionales y nacionales: Una herramienta útil para la investigación, docencia y producción agropecuaria. EDINCA, Instituto Nacional de Ciencias Agrícolas. La Habana, Cuba, p. 61.

5. Keviste A, Alvarez JG, Rojo A (2002) Funciones de crecimiento de aplicación en el ámbito forestal. Ministerio de Ciencia y Tecnología. Instituto de Investigaciones y Tecnología Agraria y Alimentaria. Madrid. España.

6. Guerra C, Cabrera A (2003) Criterios para la selección de modelos estadísticos en la investigación científica. Revista Cubana Ciencias Agrícolas 37(1): 3-10.
7. Torres V, Ortiz J (2005) Application of modelling and simulation to the production and feeding of farm animals. Cuban J Agric Sci 39: 397-405.

8. Verdecia DM, Ramírez JL, Bodas R, Leonard I, Giráldez FJ, et al. (2011) Rendimiento productivo y composición química del arbusto forrajero Tithonia diversifolia en una zona del valle del Cauto, Cuba. En: Pastos, paisajes culturales entre tradición y nuevos paradigmas del siglo XXI, López C, Rodríguez MP, San Miguel A, Fernández F, Roig S (Eds.), Sociedad Española para el estudio de los Pastos, Madrid. España, pp. 613-618.

9. Ríos CI (1999) Tithonia diversifolia (Hemsl.) Gray, una planta con potencial para la producción sostenible en el trópico. En: Sánchez MD, Rosales M (Eds.), Agroforestería para la Producción Animal en América Latina. Estudio FAO Producción y Sanidad Animal N 143 . FAO, Roma, Italia, pp. 311-325.

10. Mahecha L, Escobar JP, Suárez JF (2007) Tithonia diversifolia (hemsl.) Gray (botón de oro) como suplemento forrajero de vacas F1 (Holstein por Cebú). Livestock Research for Rural Development 19(2).

11. Ruiz TE, Febles GJ, Torres V, González J, Achang G, et al. (2010) Evaluación de materiales recolectados de Tithonia diversifolia (Helmsl) Gray en una zona centro-occidental de Cuba. Revista Cubana de Ciencias Agrícolas. 44(3): 291-296.

12. Sanchez T, Lamela L, López O (2007) Caracterización de la comunidad vegetal en una asociación de gramíneas mejoradas y Leucaena leucocephala cv. Cunningham. Pastos y Forrajes 30(4): 455-467.

13. Mendoza H, Tzec GS (2000) Efecto de las frecuencias de rebrote sobre la producción y calidad del follaje del árbol "Ramón" (Brosimum alicastrum Swartz). Livestock Research for Rural Development 12(4): 1-12.

14. Simon L, Hernández I, Ojeda F (1998) Protagonismo de los árboles en los sistemas silvopastoriles. En: Los árboles en la ganadería. Tomo I, Simón L (Eds.), EEPF “Indio Hatuey”. Matanzas, Cuba. p. 28.

15. Sosa EE, Cabrera E, Pérez D, Ortega L (2008) Producción estacional de materia seca de gramíneas y leguminosas forrajeras con corte en el estado de Quintana Roo. Téc Pecu Méx 46(4): 413-426. 